\title{
AGROECOLOGIA E REFORMA AGRÁRIA: UM ESTUDO SOBRE AS PRÁTICAS AGROECOLÓGICAS NO ASSENTAMENTO CELSO FURTADO, PARANÁ
}

\author{
Jucélia Valeriano da Silva \\ Universidade Federal da Fronteira Sul - Campus Laranjeiras do Sul, Paraná, Brasil \\ juceliavalleriano@gmail.com \\ Roberto Antônio Finatto \\ Universidade Federal da Fronteira Sul - Campus Laranjeiras do Sul, Paraná, Brasil \\ robertofinatto@gmail.com \\ Márcio Freitas Eduardo \\ Universidade Federal da Fronteira Sul - Campus Erechim, Rio Grande do Sul, Brasil \\ marcioeduardo@uffs.edu.br
}

\begin{abstract}
RESUMO
A partir do ano 2000, articulada à luta pela terra, a Agroecologia se constituiu como uma importante pauta do Movimento dos Trabalhadores Rurais Sem Terra (MST). Entretanto, o desenvolvimento das práticas agroecológicas em áreas de reforma agrária enfrenta uma série de entraves para a consolidação da Agroecologia como a principal matriz produtiva nos acampamentos e nos assentamentos. Este artigo tem como objetivo analisar, com base em uma perspectiva histórica e relacional, o desenvolvimento das práticas agroecológicas no assentamento Celso Furtado, localizado no município de Quedas do Iguaçu, Paraná. A pesquisa teve cunho teórico e empírico, com tratamento qualitativo dos dados. Foram realizadas entrevistas com os agricultores de diferentes comunidades do assentamento, além de trabalhos de campo nas unidades de produção, a fim conhecer o histórico de implantação da Agroecologia no período do acampamento e caracterizar como as práticas agroecológicas estão sendo realizadas atualmente. Identificamos que 0 trabalho desenvolvido pelo MST, em conjunto com outras instituições, possibilitou a territorialização das práticas de Agroecologia nos acampamentos 10 de Maio e José Abílio dos Santos. Entretanto, por motivos diversos, após a formação do assentamento Celso Furtado houve descontinuidades que implicaram processos de desterritorialização das ações de fomento à Agroecologia. Atualmente, a prática agroecológica está reduzida a pequenas áreas, mas, ainda assim, sua presença se apresenta como resistência ao modelo de produção convencional.
\end{abstract}

Palavras-chave: Agroecologia. Acampamento. Assentamentos rurais. Território.

\section{AGROECOLOGY AND LAND REFORM: A STUDY ON AGROECOLOGICAL PRACTICES AT CELSO FURTADO RURAL SETTLEMENT - PARANA}

\begin{abstract}
Beginning in the 2000s, Agroecology has constituted itself as an important topic of discussion for the Landless Workers' Movement (MST). However, the development of agroecological practices in land reform areas faces a series of obstacles that complicate the consolidation of the agroecology as the main production matrix in these places. Thus, this article aims to analyze, through a historical and relational perspective, the development of agroecological practices at Celso Furtado rural settlement, located in Quedas do Iguaçu, Paraná. The research possesses both theoretical and empirical natures regarding qualitative data processing. Interviews were conducted with farmers from different communities within the settlement. Moreover, fieldwork was performed in production unities in order to verify the history of agroecology implementation during a time when such a location was a land reform camp and to typify what kinds of agroecological practices are currently handled there. As a result, we identified that MST's work, along with other institutions, has made it possible for the Agroecology territorialization at 10 de Maio and José Abilio dos Santos camps. Nevertheless, for several reasons, after Celso Furtado became a settlement there were
\end{abstract}


discontinuities that promoted the process of deterritorialization of agroecology fostering actions. Today, agroecological practices have been narrowed down to few areas, although they present themselves as a resistance to the conventional production model.

Keywords: Agroecology. Rural camps. Rural settlements. Territory.

\section{INTRODUÇÃO}

A Agroecologia pode ser considerada uma ciência, uma prática e um movimento social (WEZEL et al., 2009; ABA, 2019), sendo desenvolvida em um conjunto variado de contextos estruturados em torno das relações familiares de produção. Considerando-se o potencial da Agroecologia para a soberania alimentar (ALTIERI, 2010), a preservação e a valorização da diversidade ecológica e sociocultural (GUZMÁN, 2001), ela é promovida por um conjunto de movimentos e organizações sociais, instituições públicas e diferentes iniciativas que envolvem desde os agricultores até os consumidores dos produtos.

O Movimento dos Trabalhadores Rurais Sem Terra (MST) é um dos movimentos sociais populares que difunde a Agroecologia enquanto parte de um processo mais amplo de luta pela terra. Diante disso, este trabalho tem como objetivo analisar, com base em uma perspectiva histórica e relacional, o desenvolvimento das práticas agroecológicas no assentamento Celso Furtado, localizado no município de Quedas do Iguaçu, estado do Paraná. Formado em dezembro de 2004, o espaço foi organizado pelo MST e conta com 1.004 famílias assentadas (INCRA, 2017), constituindo-se no maior assentamento do estado do Paraná e um dos maiores da América Latina.

Esta análise considera o território como produto das relações sociais construídas em determinado espaço e tempo, ou seja, enquanto resultado da ação desenvolvida pelos sujeitos. Assim, interessa-nos compreender como o desenvolvimento da Agroecologia nos acampamentos e assentamentos de reforma agrária se articula à construção de um projeto territorial proposto pelo MST, nas dimensões material e imaterial, que se contrapõe ao modelo convencional de produção agropecuária vinculado ao agronegócio.

O texto também busca contribuir, especificamente, para o debate da Agroecologia nas áreas de acampamentos da reforma agrária (Cf. PICCIN, 2009; BOZA et al., 2011; SILVA, 2011; FACCO, 2015; FERNANDES e FACCO, 2015; FONSECA, 2017; FINATTO e RIBAS, 2017; MARTIM, 2017; RODRIGUES, 2018; SILVA; 2018 SILVA et al., 2018), tema menos explorado em pesquisas acadêmicas quando comparado às análises direcionadas exclusivamente à Agroecologia nos assentamentos rurais. Portanto, reforçamos a necessidade de melhor compreender-se como a Agroecologia se insere e é desenvolvida naqueles espaços, visto que isso influencia diretamente no sistema produtivo adotado e nas dinâmicas territoriais desenvolvidas, posteriormente, nos assentamentos.

O texto se estrutura em três partes principais: após a apresentação da metodologia da pesquisa, tratamos da Agroecologia e da reforma agrária em uma perspectiva territorial, entendendo que as práticas agroecológicas revelam a implantação de um projeto - político, ambiental, social e econômico - para as áreas de reforma agrária; na sequência, são apresentados os principais processos históricos que desencadearam a formação do assentamento Celso Furtado; por último, evidenciamos os avanços das práticas agroecológicas nos acampamentos 10 de Maio e José Abílio dos Santos (que antecederam a criação do assentamento) e os limites para a sua consolidação, enquanto projeto, na implantação do referido assentamento.

\section{METODOLOGIA}

A pesquisa apresentada é de natureza teórica e empírica, com tratamento qualitativo dos dados amparado, sobretudo, na análise do discurso dos entrevistados em conjunto com a bibliografia sobre a área e o tema de estudo.

Foram realizadas entrevistas baseadas em roteiros semiestruturados com cinco moradores do assentamento Celso Furtado, sendo que dois deles participaram ativamente do processo de sensibilização e desenvolvimento da Agroecologia nos acampamentos que antecederam a formação do assentamento, ou seja, nos acampamentos 10 de Maio e José Abílio dos Santos.

As entrevistas foram realizadas de janeiro a março de 2019 , nas unidades de produção dos assentados, e foram transcritas e analisadas posteriormente. As incursões nas unidades de produção permitiram 
conhecer as áreas de cultivo, a territorialidade dos camponeses e os desafios para viabilizar a produção agroecológica. As entrevistas foram realizadas com os sujeitos que possuem forte inserção na área de estudo e que puderam fornecer, portanto, uma visão ampla dos processos em curso na área, notadamente aqueles relacionados com a Agroecologia.

Ademais, partimos das informações e das lacunas apresentadas pela bibliografia representativa da área de estudo da Agroecologia (BOZA; PEREIRA; XAVIER, 2011; SILVA, 2018; SILVA; PAVINATO; AHLERT, 2018; MARCELITES, 2018; RODRIGUES, 2018).

\section{TERRITÓRIO, AGROECOLOGIA E REFORMA AGRÁRIA}

Para analisar o processo de (des)territorialização da Agroecologia no assentamento Celso Furtado, é necessário, antes, compreender o sentido do conceito de território. Mais do que isso, compreender como as disputas territoriais são estruturantes da questão agrária brasileira (PAULINO e FABRINI, 2008).

A designada "luta pela terra" exprime, como conteúdo, a defesa de um projeto de vida e de trabalho do qual o território é um trunfo imprescindível. Como bem nos lembra Raffestin (1993, p. 143), "o território se forma a partir do espaço". A existência do espaço antecede a do território e, a partir do momento em que o ator se apropria de um espaço, ele o territorializa.

O território é a forma com que um ator idealiza, constrói, normatiza, dota de legitimidade e organiza determinada porção do espaço através de sucessivas ações de territorialização, convergindo, para tanto, a energia e o componente informacional. Como sustém Raffestin (1993), o território é um espaço onde se projetou um trabalho (energia e informação) e, por essa circunstância, revela relações marcadas pelo poder. É, portanto, na condição de um campo relacional, uma das expressões geográficas da ação social e histórica (EDUARDO, 2006).

A energia é a capacidade dos sujeitos de mobilizarem esforços e recursos para a realização de um projeto. A informação é o próprio fluxo multidirecional das ideias, das aspirações e dos conhecimentos. Energia e informação se combinam em um campo relacional - portanto, de poder - repleto de contradições e de potencialidades e se materializam nas ações cotidianas por meio do trabalho e das mediações político-culturais e ecológicas. O território, com seus limites mais ou menos tangíveis, é essa produção elaborada a partir do espaço.

O território, na luta dos sem-terra, significa um movimento, um trunfo, na direção de (r)estabelecer as condições concretas e subjetivas para combinar energia e informação sob a tutela de um projeto próprio, de uma maior autonomia relativa no que concerne ao modelo de desenvolvimento do agronegócio (o qual sustém um sistema agroalimentar convencional e globalizado). Convergem, para isso, a terra, o trabalho e as intencionalidades e mediações subjacentes.

O trabalho divorciado da propriedade ou da posse da terra está reduzido a condição de força de trabalho, a um "trabalho abstrato" (ANTUNES, 2003), no sentido de que a energia (manifestada pela ação do trabalhador) está em desalinho com as determinações provenientes da informação, isto é, com os projetos e intencionalidades que ordenam os fluxos de energia. O poder, reconhece Raffestin (1993), está intimamente ligado à manipulação dos fluxos que atravessam e desligam a relação entre a energia e a informação. Portanto, o poder se enraizaria no trabalho. $O$ trabalho é energia informada.

Apropriar-se do trabalho significa destruí-lo ou, mais exatamente, submetê-lo a uma dicotomia e separar a energia da informação: apropriar-se de uma e/ou de outra. No fundo, é impedir o homem de dispor de uma e de outra ao mesmo tempo, o que, consequentemente, significa privá-lo de sua capacidade primitiva de transformação (RAFFESTIN, 1993, p. 56-57).

A luta pela terra, preconizada pelos "movimentos socioterritoriais" do Brasil (FERNANDES, 2013), é um projeto em permanente construção. A conquista da terra, como dimensão tangível da reforma agrária, tem se imbricado, progressivamente, a dimensões mais ou menos intangíveis, onde habitam os vetores da informação (como no caso dos conhecimentos em torno da Agroecologia), para a territorialização de práticas mais alinhadas aos desafios de permanecer na terra e de desenvolver autonomias na definição dos projetos de vida e de trabalho.

O atino para a Agroecologia, por parte do MST, intenciona fazer interagir a energia, proveniente da luta pela terra, com a informação a respeito do projeto de autonomia possível, realizável por meio do manejo sustentável dos agroecossistemas, transformando energia e informação em saberes e arranjos específicos da reforma agrária. Na disputa territorial entre o campesinato e o agronegócio, cada vez mais

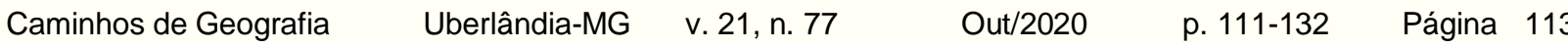


frequentemente tem se apresentado a colagem entre a reforma agrária como condição para a produção de alimentos saudáveis, segundo os parâmetros de segurança alimentar e nutricional. A luta pela terra pari passu à luta pelo alimento e pela sociobiodiversidade são conteúdos atuais da reforma agrária e encontram ressonância nos movimentos globais de crítica às mudanças climáticas.

Nas áreas de reforma agrária, a Agroecologia se erige, concomitantemente, como um enfoque (reitera-se sua qualidade informacional, capaz de orientar as ações político-organizativas) e como uma prática produtiva com potencialidades de estabelecer outras conexões entre o trabalho e o território (com base na energia socioprodutiva cooperada com a energia da natureza). Isso vai de encontro ao modelo de desenvolvimento do agronegócio, o qual, ao desligar a informação e o saber do território, subordina para explorar. Assim, procede-se à "monopolização do território pelo capital" (OLIVEIRA, 2001a).

Nas disputas territoriais entre os diferentes projetos de desenvolvimento, os sujeitos e suas organizações sociais desenvolvem práticas que demarcam as intencionalidades subjacentes e, assim, territorializam o espaço. Neste texto, usamos os termos "territorialização" e "desterritorialização" da Agroecologia para ressaltar as dimensões materiais e imateriais das ações desenvolvidas pelos integrantes do MST enquanto atores sintagmáticos (RAFFESTIN, 1993) - e que possibilitaram o avanço (territorialização) ou a retração (desterritorialização) da Agroecologia na área estudada. Os dois termos em destaque devem ser, portanto, compreendidos no conjunto das reflexões em que foram produzidos.

No intento de compreender alguns elementos históricos atrelados ao processo de luta pela terra, cabe mencionar que a formação socioespacial brasileira, sobretudo no que se refere a sua estrutura fundiária, revela diferentes intencionalidades e projetos de poder, produzindo conflitualidades. A história do país é marcada por vários entraves que dificultaram o acesso à terra pela população trabalhadora. Zeneratti (2017) destaca que, em 1824, com a Constituição Imperial, foi legalizada a propriedade privada no Brasil, porém, antes disso havia a lei das Sesmarias. Essa lei, extinta somente em 1822, destinava terras devolutas para a produção aos homens de grande poder político e econômico, os senhores fidalgos. As terras deveriam ser distribuídas apenas para aqueles que tinham condições de explorá-las.

Com o desenvolvimento e a expansão do modo capitalista de produção, a terra tornou-se propriedade privada. A Constituição Imperial veio como instrumento na defesa dos direitos dos cidadãos, inclusive o direito da propriedade, porém, esse direito só pertencia a quem dispunha de capital para explorar a terra. Posteriormente, a Lei de Terras (Lei n. 601), em 1850, regularizou a existência do latifúndio e, a partir de então, a terra passa a ser mercadoria, com a compra e a venda regulando o seu uso. Por outro lado, a lei permitiu a formação do campesinato proprietário. Assim, "o latifúndio foi se formando juntamente com a classe de proprietários, seja pela aquisição de terras ainda durante o regime das sesmarias e, posteriormente, tornadas propriedade privada pela Constituição Imperial, seja comprando-as já sob a Lei de Terras." (ZENERATTI, 2017, p. 446).

Por parte da elite fundiária do país, essa regularização legitimou a apropriação da terra em grandes extensões. Sendo a compra o único meio de obtenção das terras, os trabalhadores foram, de certa forma, "privados" desse direito, criando-se, assim, um mecanismo de bloqueio aos trabalhadores (MARTINS, 2010). Com a concentração de terra e a demanda de produzir em grandes áreas surge a necessidade de maquinários e insumos agrícolas que viabilizem a produção. Assim, com forte apoio do Estado brasileiro, a partir da década de 1960, molda-se o processo de modernização da agricultura com a inserção de máquinas agrícolas, insumos e fertilizantes de origem urbano-industrial na agricultura.

Segundo Delgado $(2005$, p. 56$)$ "a modernização agrícola sem reforma agrária é um dos pensamentos conservadores que foi impondo mesmo que lentamente a demanda por produtos agrícolas e seus efeitos nos preços, emprego e comércio exterior, mas sem pautar sobre as consequências reais para o país". Esse processo de modernização técnica da agricultura e de integração com a indústria é caracterizado

\begin{abstract}
Por um lado, pela mudança na base técnica de meios de produção utilizados pela agricultura, materializada na presença crescente de insumos industriais (fertilizantes, defensivos, corretivos do solo, sementes melhoradas e combustíveis líquidos etc.), e de máquinas industriais (tratores, colhedeiras, implementos, equipamentos de irrigação etc.). De outro lado, ocorre uma integração de grau variável entre a produção primária de alimentos e matérias-primas e vários ramos industriais (oleaginosos, moinhos, indústrias de cana e álcool, papel e papelão, fumo, têxtil, bebidas etc.). (DELGADO, 2005, p. 58).
\end{abstract}

É nesse contexto que o agronegócio se territorializa no Brasil, com forte apoio do Estado, por meio da artificialização do processo produtivo e da intensa relação com a indústria. Assim, "o território do agronegócio se fundamenta na integração corporativa dos produtores liderada pelas empresas, que reconfiguram o espaço em função da lógica produtiva." (CAVALCANTE e FERNANDES, 2008, p. 23).

$\begin{array}{lllll}\text { Caminhos de Geografia } \quad \text { Uberlândia-MG } & \text { v. 21, n. } 77 & \text { Out/2020 } & \text { p. 111-132 Página } 114\end{array}$


A modernização da agricultura se estruturou, portanto, com base no capital necessário para a compra de insumos e maquinários, especialmente nas médias e grandes propriedades. Esse processo histórico sobre o acesso à terra e a modernização conservadora da agricultura resultou em impactos sociais, econômicos e ambientais diversos. Balsan (2006, p. 128) afirma que "dentro de uma ótica global, a modernização agrícola nos revela que, por meio dos processos históricos, a propriedade da terra foi sendo subordinada ao capital."

Contudo, a territorialização do agronegócio não acontece sem resistência. As contradições e as disputas entre diferentes modelos de desenvolvimento produzem as conflitualidades no campo (FERNANDES, 2008). Assim, a partir das disputas travadas entre o agronegócio latifundiário e os camponeses, o território se apresenta como expressão das contradições sociais (FABRINI e ROOS, 2014).

A conflitualidade faz surgir vários movimentos contestatórios, questionando os rumos do desenvolvimento, como o MST. O surgimento de movimentos sociais foi uma grande conquista dos trabalhadores. Entre eles, o MST é um dos principais, sendo liderado por trabalhadores rurais na luta pela reforma agrária. O MST surgiu na década de 1980, constituindo-se no principal movimento de luta do campesinato, sobretudo por sua sólida organização e abrangência nacional (OLIVEIRA, 2001b). Trata-se de um movimento para "entrar na terra", "terra que tem sido mantida improdutiva e apropriada privadamente para servir de reserva de valor e/ou reserva patrimonial às classes dominantes." (OLIVEIRA, 2001b, p. 194).

Vale ressaltar que o MST não é o único movimento que promove a luta contra o domínio do capital no campo e na produção de alimentos. A luta dos povos indígenas pela demarcação de seus territórios e a luta dos camponeses contra as grandes obras do Estado que causam a desapropriação de muitos trabalhadores de suas terras resultaram em movimentos. Como exemplos estão o Movimento dos Atingidos por Barragens (MAB) e o Movimento dos Pequenos Agricultores (MPA), os quais, cada um com suas especificidades, lideram uma luta coletiva contra os avanços do capital. Entre os anos 2000 e 2016 , atuaram nas distintas regiões do Brasil 137 movimentos socioterritoriais, o que comprova tamanha diversidade e expressividade das lutas e dos problemas sociais no campo brasileiro (DATALUTA, 2017).

Nesse sentido, a necessidade de construir alternativas que atendam às demandas dos camponeses se apresenta como fundamental, já que, conforme Leff (2002, p. 38), com a globalização "a terra foi desterritorializada e o camponês foi 'descampesinado', separado de sua terra e do sentido de sua existência". Caporal (2008) entende que a Agroecologia é um campo do conhecimento científico que, com base numa perspectiva holística e transdisciplinar, integra os saberes históricos dos agricultores na análise e na construção de estratégias de desenvolvimento rural e no desenho de agriculturas mais sustentáveis. Leff (2002, p. 37) também ressalta que "os saberes agroecológicos são uma constelação de conhecimentos, técnicas, saberes e práticas dispersas que respondem às condições ecológicas, econômicas, técnicas e culturais de cada geografia e de cada população".

Essa compreensão sobre a Agroecologia a coloca em posição diferente da produção orgânica. Quando evocamos o termo Agroecologia estamos nos referindo a um conjunto de mudanças qualiquantitativas, em diferentes escalas, que ultrapassam o aspecto produtivo na agropecuária. A Agroecologia, conforme assevera Guzmán (2006), abrange as dimensões ecológica e técnicoagronômica, socioeconômica e cultural e a dimensão sociopolítica.

Nesses termos, não se trata de uma agricultura de substituição de insumos e processos (ROSSET, 1997), ou seja, quando são substituídos insumos de origem sintética por aqueles naturais ou biológicos. Em certos casos, essa simples substituição já possibilita o desenvolvimento da produção orgânica, mas é insuficiente para denominá-la agroecológica, já que ela não busca mudanças estruturais no sistema agroalimentar. Portanto, mesmo que a produção orgânica considere o aspecto ambiental, "minimizando significativamente as externalidades negativas da atividade agropecuária, é no conjunto de elementos relacionados com a agricultura - ambientais, sociais, culturais, econômicos, políticos, etc. — que a agroecologia vem se projetando" (FINATTO, 2016, p. 109).

Por outro lado, a legislação que trata da produção orgânica não reconhece essas particularidades. Consta da Lei n. 10.831, de 23 de dezembro de 2003, que o "sistema orgânico de produção agropecuária" envolve um conjunto de sistemas produtivos, incluindo o agroecológico (BRASIL, 2003). O produto orgânico, portanto, por força da legislação, pode ser considerado aquele também oriundo da produção agroecológica. A denominação "orgânico", inclusive, é a que deve constar no rótulo dos produtos para ser identificada pelo consumidor.

Apesar dessa diferença conceitual e do conjunto de evidências levantadas ao longo desta pesquisa, ao apontarmos que o MST busca o desenvolvimento da Agroecologia, ou seja, avançar em relação à 
produção orgânica, os termos "produção/agricultura orgânica" e "Agroecologia" são empregados, em diferentes situações cotidianas, como sinônimos. Isso não modifica ou desqualifica a prática. Contudo, este esclarecimento conceitual é necessário para que o leitor tenha entendimento da dimensão das práticas analisadas neste estudo, mesmo que nominalmente, inclusive em alguns casos pelos próprios sujeitos que a desenvolvem, essa diferença não apareça.

O MST incorporou, em sua bandeira de luta, a concepção da Agroecologia como a matriz produtiva e organizativa fundamental para a reforma agrária. Altieri (2010, p. 29) destaca a importância dos movimentos sociais nesse processo, já que a "[...] Via Campesina e o Movimento dos Trabalhadores Rurais Sem Terra (MST) do Brasil, há muito tempo sustentam que os agricultores precisam da terra para produzir a comida para suas próprias comunidades e seu país". No entendimento de Altieri (2010, p. 30),

\begin{abstract}
Os movimentos sociais rurais compreendem que o desmonte do complexo agroalimentar industrial e a restauração dos sistemas alimentares locais devem estar acompanhados da construção de alternativas agroecológicas que satisfaçam as necessidades dos produtores em pequena escala e da população não agrícola de rendimentos baixos, o que se opõe ao controle corporativo da produção e do consumo.
\end{abstract}

Destacamos, a partir das palavras de Altieri, a importância dos movimentos em prol de um sistema produtivo viável aos camponeses, ressaltando-se novamente a importância da Agroecologia para os agricultores, para o ambiente e para os consumidores. O MST, embora já estivesse avaliando, ainda na década de 1990, os problemas da produção convencional nas áreas de reforma agrária, incorpora de maneira mais explícita a Agroecologia em suas ações no ano 2000, durante o seu IV Congresso Nacional (MARCELITES, 2017).

A incorporação da Agroecologia como bandeira de luta do MST também é resultado da avaliação das experiências desenvolvidas em assentamentos rurais, sobretudo na década de 1990. Muitas experiências de cooperativismo e coletivização da terra - embasadas nas ideias de K. Marx, K. Kautsky e V. I. Lênin não produziram o êxito esperado nos assentamentos brasileiros; assim, ganhou espaço uma perspectiva que considera a lógica camponesa - amparada nas ideias de A. Chayanov - e a questão ambiental estruturada em torno da Agroecologia (BORSATTO e CARMO, 2013).

A conjuntura política e econômica do período também contribuiu para essa mudança no MST. Pode-se destacar: a reforma neoliberal do Estado brasileiro que pôs fim às políticas setoriais de preços mínimos e abriu os mercados, dificultando a viabilidade econômica dos pequenos proprietários; o fim do Programa Especial de Crédito para a Reforma Agrária (PROCERA); a formação da Via Campesina Internacional (PICOLOTTO e PICCIN, 2008); e a existência de pessoas e instituições que militavam pela transformação do modelo de produção agrícola vigente, buscando alternativas ecológicas (BORSATTO e CARMO, 2013).

Com o reconhecimento da Agroecologia como alternativa para as áreas de reforma agrária a partir do IV Congresso Nacional do MST, o tema ganhou destaque nas ações do Movimento e fortaleceu a luta política pela transformação social. De acordo com o Programa Agrário do MST - resultado da preparação para o seu VI Congresso Nacional, em 2014 - "toda produção será desenvolvida com o controle dos trabalhadores sobre o resultado de seu trabalho", apontando à necessidade de se "utilizar técnicas agroecológicas, abolindo o uso de agrotóxicos e sementes transgênicas" (MST, 2014, p. 207).

Entretanto, como já apontaram Picolotto e Piccin (2008), essas ideias são apresentadas como orientações aos agricultores das áreas de reforma agrária. Isso produz diferenças importantes na forma como são absorvidas pelas lideranças, pelos acampados e assentados. Assim, "o fato dessas experiências estarem sendo desenvolvidas mais em alguns assentamentos e menos em outros (ou mesmo alguns não estarem sendo realizadas) não invalida a ideia, mas complexifica e repõe constantes desafios ao projeto político do Movimento" (PICOLOTTO e PICCIN, 2008, p. 27).

Na sequência, apresentamos como a incorporação do discurso e das práticas agroecológicas ocorreu nos acampamentos que deram origem ao assentamento Celso Furtado, objeto de nossa análise.

\title{
A FORMAÇÃO TERRITORIAL DO ASSENTAMENTO CELSO FURTADO
}

O assentamento Celso Furtado está localizado, em sua maior parte, no município de Quedas do Iguaçu (Figura 1), em área que estava sob domínio da empresa Araupel S. A. A empresa se estruturou na década 
de 1970, quando dois grupos do ramo madeireiro, a Giacomet S. A. e a Marodin Exportação S.A, uniramse e formaram a Giacomet-Marodin Indústria de Madeira S.A. O objetivo dessa junção foi adquirir terras na região Centro-Sul Paranaense, abrangendo cinco municípios (Espigão Alto do Iguaçu, Nova Laranjeiras, Três Barras do Paraná, Rio Bonito do Iguaçu e Quedas do Iguaçu) em uma área total de 87.167,51 hectares, constituindo, assim, o maior latifúndio em área continua do sul do país (ROOS, 2011).

Desde 1970, ocorreram vários conflitos nessa região entre os camponeses e a empresa GiacometMarodin. Porém, a maioria desses camponeses não lutava organizada em um movimento social estruturado em âmbito regional ou estadual. Esses sujeitos eram formados por posseiros que, expulsos de suas terras pela empresa, uniram-se na luta para retornar à terra. Organizados pelo MST, os camponeses entraram novamente em enfrentamento contra a empresa no ano de 1996, ocupando parte da fazenda localizada no município de Rio Bonito do Iguaçu, o que resultou na criação de dois assentamentos: Ireno Alves dos Santos e Marcos Freire (ROOS, 2011).

Figura 1 - Localização do Assentamento Celso Furtado no estado do Paraná e no município de Quedas do Iguaçu.

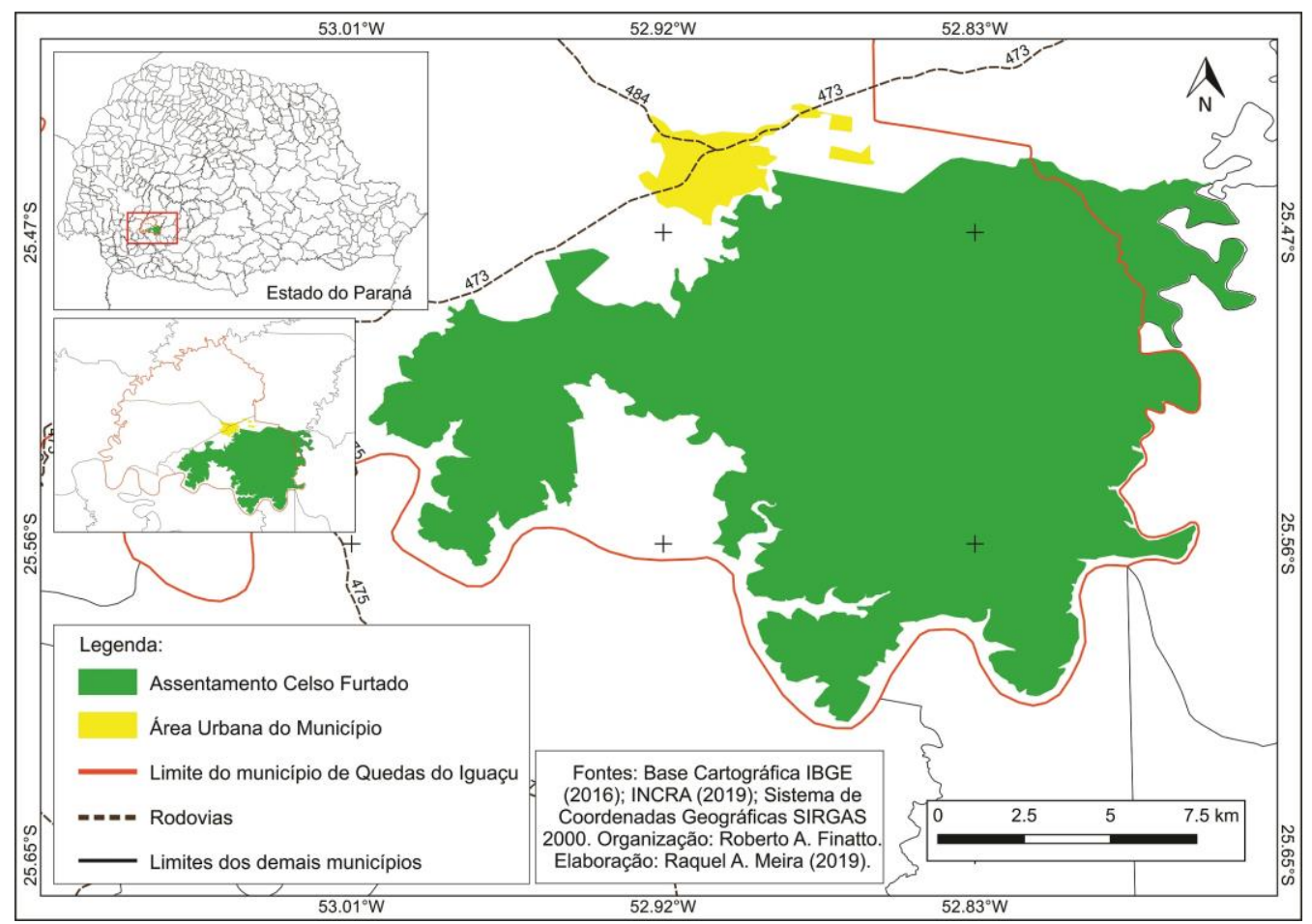

As ocupações que levariam à formação do assentamento Celso Furtado se deram muito antes de o mesmo ser oficializado. O primeiro acampamento foi formado nas margens da BR-158, entre os municípios de Rio Bonito do Iguaçu e Laranjeiras do Sul, Paraná, em 1999. As famílias que faziam parte desse acampamento eram excedentes dos assentamentos Ireno Alves dos Santos e Marcos Freire, mas também havia pessoas advindas de outras regiões, até mesmos "brasiguaios", oriundos do Paraguai (MARCELITES, 2017). As famílias excedentes ali permaneceram por volta de quatro meses, até que no dia 10 de maio de 1999 ocuparam uma área da empresa Araupel, conhecida como "Bacia", em Quedas do Iguaçu.

Entretanto, como afirma Marcelites (2017, p. 24) "as famílias do Acampamento da Bacia eram frequentemente ameaçadas de despejo, muitas delas acabaram desistindo do Movimento, consequentemente enfraquecendo a luta pela terra na área". Diante disso, outro acampamento foi formado nas margens da BR-158, entre os municípios de Laranjeiras do Sul e Rio Bonito do Iguaçu, em 2003, com o intuito de fortalecer a luta contra o latifúndio. Sendo assim, foi ocupada outra área denominada "Silo", no dia 12 de julho de 2003, localizada cerca de doze quilômetros de distância do acampamento da "Bacia" e a seis quilômetros da cidade de Quedas do Iguaçu. Uma estratégia muito bem organizada, dado que ao mesmo tempo em que existia uma ação de despejo na área da "Bacia", com a ocupação da nova área essa ação foi evitada.

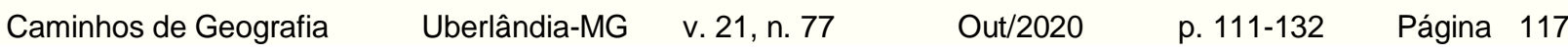


Assim, cada vez mais pessoas se aglomeravam na área do "Silo" e, com isso, a Araupel não conseguiu manter seu domínio, forçando o Instituto Nacional de Colonização e Reforma Agrária (INCRA) a destinar a área para a reforma agrária no ano de 2005. Segundo Roos (2011, p. 62),

a partir de fontes documentais, o INCRA verificou que estas terras pertenciam à União e, portanto, não havia necessidade de desapropriação da área. O INCRA entrou junto à Justiça Federal de Cascavel, com Ação Declaratória de Nulidade da titulação "non domino" que havia sido expedida pelo governo do Paraná na faixa de fronteira, dispensando assim, a desapropriação para a arrecadação destas terras para fins de reforma agrária.

Conforme Roos (2011), essa terra havia sido arrecadada através de ação judicial na data de 9 de novembro de 2004. A emissão de posse ao INCRA ocorreu em 17 de novembro de 2004 e, a partir de então, foi criado o Assentamento Celso Furtado, com um total de 25.285,53 hectares.

\section{A TERRITORIALIZAÇÃO DA AGROECOLOGIA NOS ACAMPAMENTOS 10 DE MAIO E JOSÉ ABÍLIO DOS SANTOS}

É importante destacar que quando falamos sobre a territorialização, estamos nos referindo a algo que se concretiza em um determinado espaço, mas não nos limita apenas ao espaço físico, já que o território possuí uma dimensão imaterial, e a apropriação abstrata do espaço é também parte do processo de territorialização (RAFFESTIN, 1993; EDUARDO, 2006). Os autores citados deixam claro que o território é produzido por atores, grupos ou classes sociais. Eduardo (2006, p. 180) ressalta que "os territórios são construídos socialmente pelo exercício do poder por determinado grupo ou classe social".

Nessa perspectiva, territorialização não é apenas sinônimo de chão e propriedade, mas se trata de um trabalho desenvolvido em um determinado território. Os atores que se apropriam de determinado espaço o territorializam ao desenvolverem os seus projetos com base nas relações sociais de poder e na conflitualidade. Portanto, territorializar significa, em outros termos, materializar determinada ação territorial. Por outro lado, o sentido de desterritorializar implica, de maneira sucinta, a desintegração ou o deslocamento espacial (territorial) de uma determinada ação, projeto ou trabalho. Neste texto, como já apresentado anteriormente, o termo "(des)territorialização da Agroecologia" é utilizado com o objetivo de demarcar como a Agroecologia avançou ou retrocedeu por meio das ações dos integrantes do MST.

No movimento de luta dos trabalhadores sem-terra pela reforma agrária, as relações sociais e de poder inerentes à criação dos acampamentos, à constituição do assentamento e à projeção das práticas produtivas e organizativas agroecológicas expressam, de distintas maneiras, processos sucessivos de territorialização, isto é, exprimem a construção das possibilidades espaciais (concretas e simbólicas) para que sejam viabilizadas determinadas intencionalidades e projetos (como a recriação camponesa por meio da Agroecologia, conforme abordado na pesquisa).

Assim, enquanto o território da produção convencional e do latifúndio estava sendo desconstruído, desterritorializado pela ação do movimento socioterritorial, articulavam-se ações de territorialização em direção à construção de um novo território que permitisse dar vasão à propriedade camponesa e aos códigos de territorialidade baseados nos pressupostos da Agroecologia e da organização coletiva.

Os territórios, enquanto programas desenvolvidos por diferentes atores sintagmáticos (RAFFESTIN, 1993), possuem durabilidades diferentes. Sobre esse aspecto, Souza (2000, p. 81) destaca que os "territórios são construídos (e desconstruídos) dentro de escalas temporais as mais diferentes: séculos, décadas, anos, meses ou dias; territórios podem ter um caráter permanente, mas também podem ter uma existência periódica, cíclica".

A produção agroecológica foi desenvolvida em duas áreas nos acampamentos que formariam, posteriormente, o Assentamento Celso Furtado. Tanto no acampamento 10 de Maio como no acampamento José Abílio dos Santos existiam grupos que se articulavam em torno da Agroecologia.

No caso do acampamento José Abílio dos Santos, foi formada a Brigada Orgânica, um grupo de moradores do acampamento que tinha por objetivo estabelecer a produção agroecológica no futuro assentamento, ou seja, assim que se concretizasse a conquista da terra. Na ocasião, foram reunidas as 87 famílias interessadas em trabalhar com esse sistema de produção para formar uma única brigada (MARCELITES, 2018, p. 68). 
Diante do elevado número de interessados, a Brigada contou com o apoio de organizações que trabalhavam nessa mesma perspectiva. Em parceria com o MST, a Organização não Governamental World Wide Fund for Nature (WWF) ofereceu diversos cursos técnicos para os integrantes da Brigada a fim de ampliar o seu conhecimento sobre técnicas de produção agroecológica. O Entrevistado 1 (2019) afirma que a WWF realizou uma "espécie de assessoria e motivação, mas mais de motivação, né, do que assessoria propriamente dito, então é, essa entidade que se encarregou de dar uma organicidade e dar um norte pra esse povo que tinha a intenção de produzir".

Em área próxima ao acampamento foi construída uma horta para produção de alimentos agroecológicos. Os alimentos eram destinados para o consumo das famílias acampadas e das crianças que frequentavam a escola situada no acampamento. As famílias também possuíam pequenas parcelas de terra, cerca de $6.000 \mathrm{~m}^{2}$ cada, para cultivar produtos para o autoconsumo e se manterem ativas na disputa pela terra. "Esta produção baseava-se em tubérculos, milho, arroz, feijão, enfim, produtos de gêneros alimentícios de primeira necessidade. O nível tecnológico utilizado nestas parcelas se caracterizava pelo uso de tração animal e sementes crioulas" (MARCELITES, 2017, p. 29).

Um agricultor assentado na comunidade dos Orgânicos nos relatou o que produziam na Brigada Orgânica enquanto estavam acampados, isto é, no primeiro momento da produção: "nós plantemos feijão, milho, arroz orgânico e a gente veio pra cima do lote com esse sonho de produzir orgânico" (Entrevistado 2, 2019).

No acampamento 10 de Maio, as famílias também se organizavam coletivamente e cultivavam de forma agroecológica, substituindo as sementes híbridas e fertilizantes químicos por produtos naturais. $A$ área de cada família era de cerca de $24.000 \mathrm{~m}^{2}$. A terra era fertilizada com o esterco de animais criados no próprio acampamento e, para o plantio, eram utilizadas sementes crioulas (MARCELITES, 2017). De início, alguns acampados foram convidados pelos membros da direção para integrar o grupo de produção agroecológica, conforme nos relatou um dos assentados da comunidade Palmital: "[...] aí eles convidaram a gente pra participar e a gente tinha já esse conhecimento. Então, por causa disso que a gente já aceitou esse convite, né? e [a gente] fez convite com os outros de participar, participando de reunião e conscientizando os outros também, né?" (Entrevistado 3, 2019).

Com a realização do Plano de Desenvolvimento do Assentamento (PDA), elaborado pela Cooperativa dos Trabalhadores da Reforma Agrária (COOTRARA), foi organizada uma mobilização para identificar os problemas que assolavam os moradores e levantar objetivos comuns ao grupo. Como afirma Marcelites (2017, p. 30), o PDA buscava capacitar os sem-terra para o estudo e a análise das oportunidades de desenvolvimento, o que garantiria aos trabalhadores a capacidade de elaborar projetos em suas terras. $O$ Plano buscou identificar possibilidades de geração de renda para as famílias, considerando as características da área ocupada.

O PDA revelava a preocupação com a formação em Agroecologia para a região. No documento,

além da assistência técnica para essas famílias, foi previsto a construção de uma Escola Tecnológica em Agroecologia que contemplasse a capacitação profissional nas áreas de desenvolvimento tecnológico da reforma agrária, tanto do Assentamento Celso Furtado, mas também do conjunto de assentamentos da região. (MARCELITES, 2017, p. 33)

Dessa forma, mais do que incentivos, ou recursos para manutenção da produção agroecológica, o PDA previa a inclusão social dos trabalhadores.

De acordo com Marcelites (2018), o PDA identificou três principais áreas no assentamento. Uma área de 27,9\% com a presença de vegetação nativa em estágio inicial, médio e avançado, que deveria ser manejada considerando as possibilidades de exploração agroflorestal e preservação ambiental; 23,2\% de área com a presença de madeira de reflorestamento (pinus; pinus ralo; araucária e eucalipto); e, ainda,

outra parte que compreendia a $48,9 \%$ da área do assentamento foi identificada pelo diagnóstico ambiental como as terras mais planas e de solos mais férteis, propícias para a produção de grãos. Nessa área resultaria dois sistemas produtivos diferentes, sendo a maior quantidade destinada a produção convencional dado o número de famílias que optaram por esse sistema. Outra parte da área totalizando 109 lotes, foi reservada para as famílias que mostraram interesse em produzirem de forma orgânica ${ }^{1}$." (MARCELITES, 2018, p. 56).

1 Marcelites (2018) aponta a existência de 87 famílias pertencentes à comunidade dos Orgânicos e 22 à comunidade Palmital. Por isso, são 109 lotes para a produção orgânica.

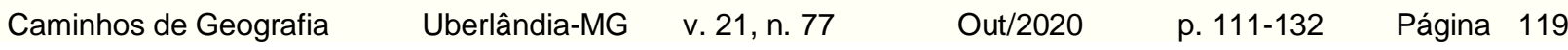


A WWF se inseriu nos processos formativos do acampamento e as lideranças fizeram uma seleção de quem seriam os acampados que teriam interesse em produzir, exclusivamente, em sistema agroecológico, bem como em participar das formações. Como relata um assentado da comunidade dos Orgânicos, em entrevista,

"[...] era assim: eles trabalhavam, [...] tenta tirar ou colocar, tirar ou colocar na mente de cada um que tinham que ser assentados o que ia ser ou o que queria ser depois que pegasse lote, com o que queria trabalhar, como que ia trabalhar, como é que ia trabalhar, qual era o sonho e era montado as oficinas, sabe?" (Entrevistado 2, 2019).

Pelas informações do agricultor, podemos identificar que as formações tinham dois grandes objetivos: sensibilizar para a importância da produção agroecológica, fazendo o planejamento do futuro lote com base nos seus princípios; e disseminar o conhecimento técnico para viabilizar a produção - escolha da melhor semente para o plantio, técnicas de armazenamento de sementes, preparação de caldas com base em plantas nativas, técnicas de controle biológico, entre outras.

Outro entrevistado, da comunidade Palmital, declarou que, depois de assentados, os agricultores receberam outros cursos de preparação para trabalhar na unidade produtiva: "depois que viemos pro assentamento, aqui teve bastante curso, né? Trabalho do SEBRAE², bastante curso. Preparação, manejo, assim, conhecimento pra esses lados, assim, intercâmbio" (Entrevistado 3, 2019). Alguns cursos eram realizados fora dos acampamentos e os cursistas eram responsáveis por compartilhar os aprendizados com os demais integrantes do grupo no retorno.

No acampamento, tanto a produção convencional como a agroecológica eram coletivas. Os interessados em produzir com base nos princípios da Agroecologia receberam, das lideranças do acampamento, uma área mais específica para desenvolverem a produção.

[...] tinha uma equipe, tinha 3, 4 pessoas que, vamos dizer assim, que coordenavam. Então essas 3, 4 pessoas saiam, deixavam o serviço, pegavam bicicleta ou cavalo, negócio assim, e ia lá olhar o que tinha que ser feito. Se era pra começar a preparar o terreno, eles chegavam e diziam: "tal dia quem tem boi, vai com boi; quem tem cavalo, faz com cavalo e vamo mexer naquela terra lá, preparar, preparar". Daí lá nós já fazia uma conversa com todos os grupos, aquele que não tinha cavalo, não tinha boi, essas coisas, metia uma foice, metia uma enxada e faziam. (Entrevistado 3, 2019).

Como já ponderado, tanto o trabalho na área quanto os produtos dele resultantes eram coletivos. "[...] Na época, nós fazia dois plantios, no cedo e no tarde, na safrinha que nem falam hoje. No cedo nós plantava feijão; e no tarde, plantava o milho" (Entrevistado 3, 2019).

Ainda, em entrevista, um assentado relatou que havia indicativos de que os acampados que aderissem à produção agroecológica teriam prioridade no processo de seleção dos lotes no posterior assentamento. Esse foi um dos motivos que levou ao aumento do número de pessoas interessadas pela Agroecologia, a priori, nos acampamentos. Interesses, por seu turno, que potencialmente poderiam representar mais 0 desejo das famílias camponesas em acessar a terra em situações de privilégio, e menos os engajamentos genuínos pelo projeto agroecológico a posteriori, no futuro assentamento. Essa tendência é comprovada com a desterritorialização da Agroecologia no movimento de transição acampamentos-assentamento, como veremos na sequência. Segundo entrevistado da comunidade dos Orgânicos: "o grupo orgânico sempre teve prioridade, sempre, tanto que é umas das causas, teve gente que se aproveitou da oportunidade porque foi citado: quem optar pelo orgânico vai ser assentado antes, aí 'choveu de gente', né? 'choveu de gente"'. (Entrevistado 2, 2019).

\section{A CONQUISTA DA TERRA E A DESTERRITORIALIZAÇÃO DA AGROECOLOGIA}

No ano de 2005, com a implantação do assentamento Celso Furtado, foram formadas duas comunidades onde a produção seria exclusivamente agroecológica: a comunidade Palmital (resultado do trabalho do grupo no acampamento 10 de Maio) e a comunidade dos Orgânicos (resultado do trabalho do grupo no

${ }^{2}$ Considerando a natureza das ações desenvolvidas pela instituição citada, o entrevistado, possivelmente, queria mencionar o Serviço Nacional de Aprendizagem Rural (SENAR) e não o Serviço Brasileiro de Apoio às Micro e Pequenas Empresas (SEBRAE). 
acampamento José Abílio dos Santos) (Figura 2) ${ }^{3}$. A comunidade Palmital era constituída por 30 famílias (RODRIGUES, 2018) e a comunidade dos Orgânicos era composta por 87 famílias (MARCELITES, 2018).

Figura 2 - Comunidades de produção agroecológica no assentamento Celso Furtado.

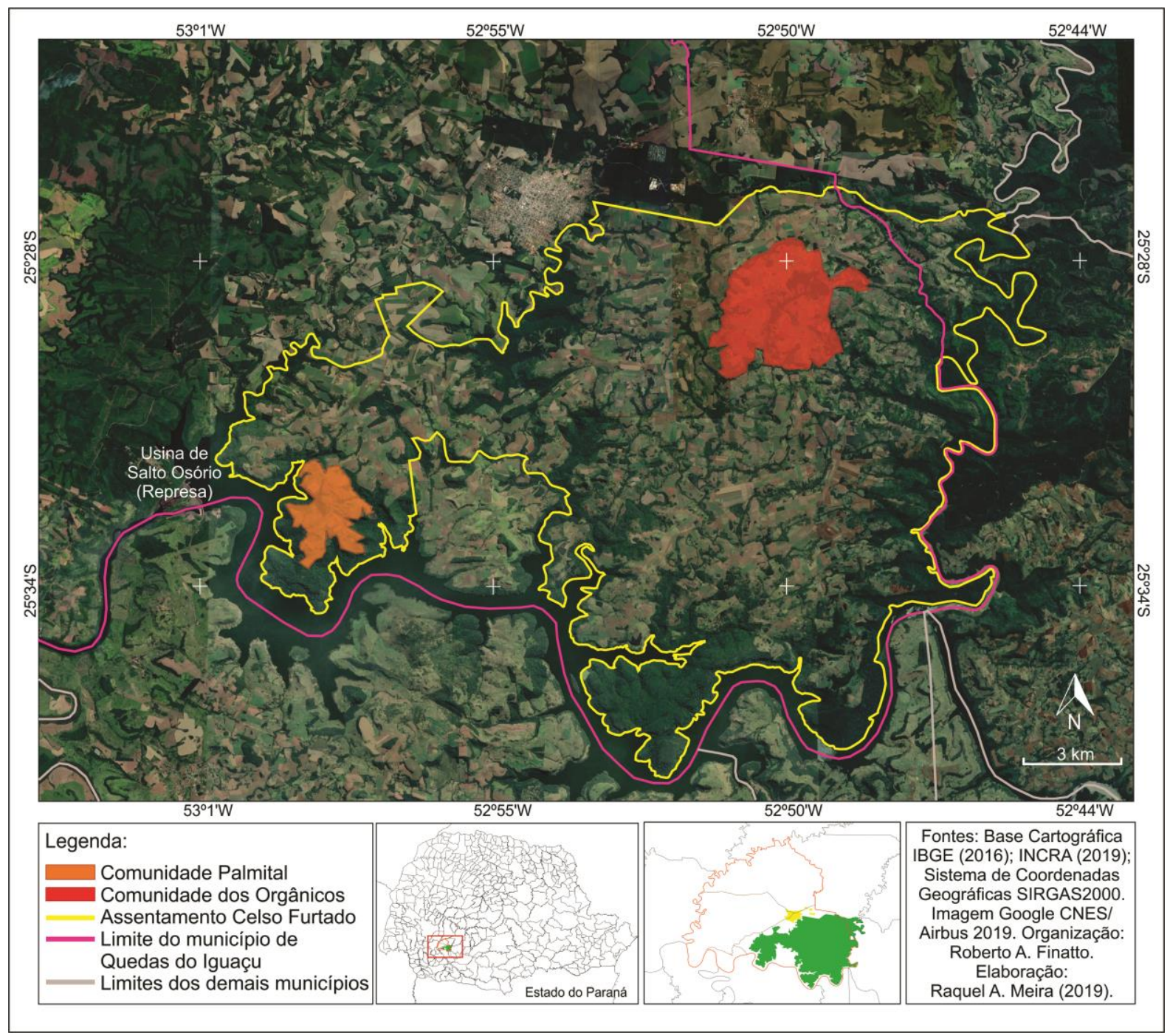

A escolha da área onde seriam as comunidades tomou como base a parte do assentamento que oferecesse condições mais favoráveis para os cultivos em sistema agroecológico, considerando também a distância das lavouras com produção convencional.

A área da comunidade Palmital era coberta por espécies nativas, por isso foi destinada para a produção agroecológica. Segundo um dos entrevistados,

[...] falavam que essa área aqui era intacta, que ninguém tinha entrado aqui dentro, [...] a madeira melhor já não existia mais aqui, já tinham tirado. Aí foi levado esse conhecimento ali pro MST, né? O pessoal da parte ambiental lá e daí, de lá de cima, veio uma equipe da parte ambiental pra entrar nessa área aqui. (Entrevistado 3, 2019).

A área da comunidade Palmital se localiza em uma das extremidades do assentamento Celso Furtado, fazendo divisa com a represa da Usina Hidrelétrica de Salto Osório (Mapa 02). Essa posição geográfica e as características físicas citadas pelo entrevistado foram fundamentais para que fosse destinada ao grupo com interesse na Agroecologia. Assim, "acreditava-se que a utilização desta área, evitaria algumas

\footnotetext{
${ }^{3}$ A delimitação das duas comunidades apresentada na figura 2 foi realizada durante o trabalho de campo pelos agricultores entrevistados a partir da observação do mapa do assentamento. Diante disso, os seus limites podem, em alguns trechos, não corresponder exatamente aos da área real das comunidades citadas.
}

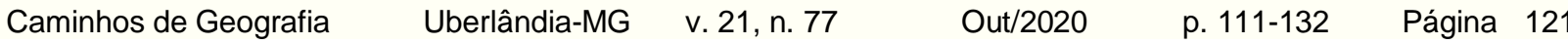


consequências dos efeitos deletérios da agricultura convencional aos agroecossistemas, como exemplo os resíduos de agroquímicos sintéticos" (RODRIGUES, 2018, p. 28).

Silva et al. (2018, p. 38) também esclarecem que a área da comunidade Palmital foi escolhida considerando as suas características físicas:

\begin{abstract}
Acreditava-se que pelo fato da a terra não haver sido cultivada anteriormente, haveria menos dificuldades com o controle de plantas espontâneas, facilitando assim a prática agroecológica. A assembleia feita para a distribuição da terra concordou com a destinação dessa área para os três grupos que formaram uma comunidade que recebeu o nome de "Palmital", devido à incidência de palmeiras naquela região.
\end{abstract}

A área cedida para a Comunidade dos Orgânicos, na parte do Acampamento José Abílio dos Santos, da mesma forma, era coberta por vegetação. O Entrevistado 2 (2019), da comunidade dos Orgânicos, afirmou: "Essa área aqui, ela foi escolhida pra os orgânicos por causa da área do mato, mais protegida e mato não tem veneno, aí foi, na época era 88 famílias".

Assim, com a mudança para os lotes individuais, um novo processo relacionado com a produção agroecológica se inicia e as famílias enfrentaram o desafio de desenvolver a produção nas novas áreas. Quando já assentadas, poucas famílias deram continuidade à produção agroecológica nos seus lotes, pois elas esperavam que os recursos e os benefícios para o grupo se concretizassem, o que não ocorreu (BOZA et al., 2011). Apesar desses limites, houve a preparação das áreas e o plantio em sistema agroecológico nos primeiros anos de assentamento (Figuras 3, 4, 5 e 6).

Figuras 3 e 4 - Preparação das áreas para o plantio na comunidade dos Orgânicos, 2005.
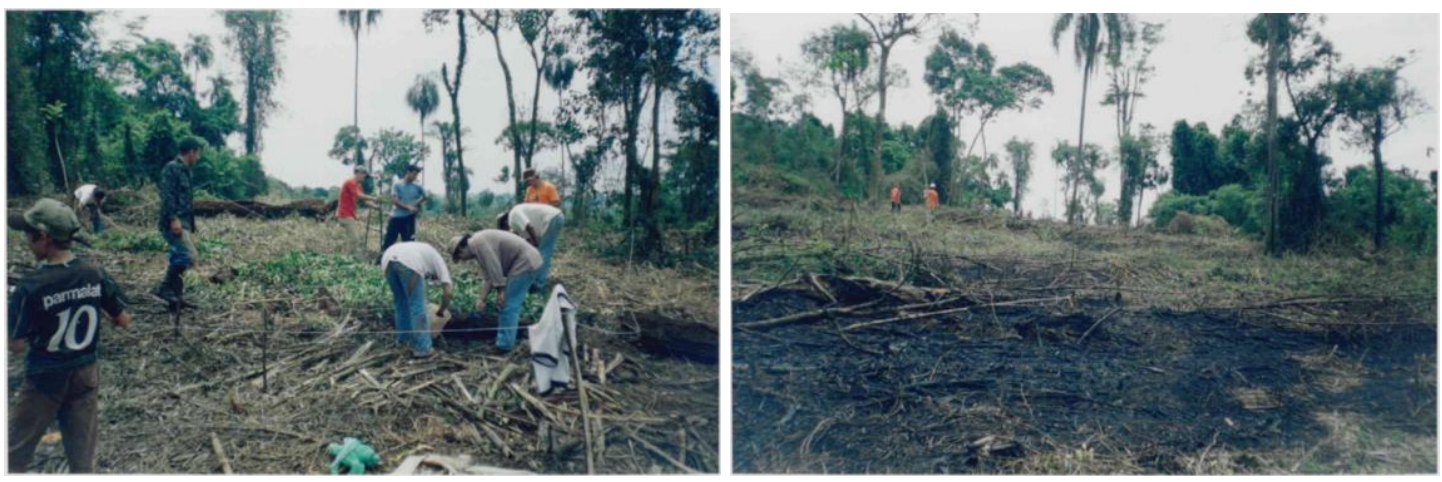

Fonte - Acervo de Elisângela Mocellin (2005).

Como é possível observar nas imagens (Figuras 3 a 6), os agricultores não conseguiram incorporar tecnologias modernas para o manejo dos agroecossistemas. Foram utilizadas técnicas e instrumentos típicos de uma agricultura em sistema tradicional, sem diminuir a penosidade do trabalho, a exemplo do manejo via queimada, típico do sistema de coivara. Esse fator contrasta com a expectativa precedente das famílias, a saber: a prosperidade produtiva e econômica que a conquista da terra provavelmente desencadearia. Essa situação certamente contribuiu para a sua desterritorialização.

A morosidade na liberação dos recursos após a formação do assentamento, bem como a burocracia para regularizar cada família em seus devidos lotes acabaram limitando muitos dos processos em andamento oriundos do período do acampamento, como é o caso da produção agroecológica. Destacamos nas falas dos entrevistados, os quais são assentados nas comunidades designadas para a produção agroecológica, os motivos que os levaram a desistir desse sistema de produção. De antemão, muitos acampados só adentraram aos grupos orgânicos pela possibilidade de receberem seus lotes e os recursos com antecedência. 
Figuras 5 e 6 - Áreas de produção da comunidade Palmital, 2005.

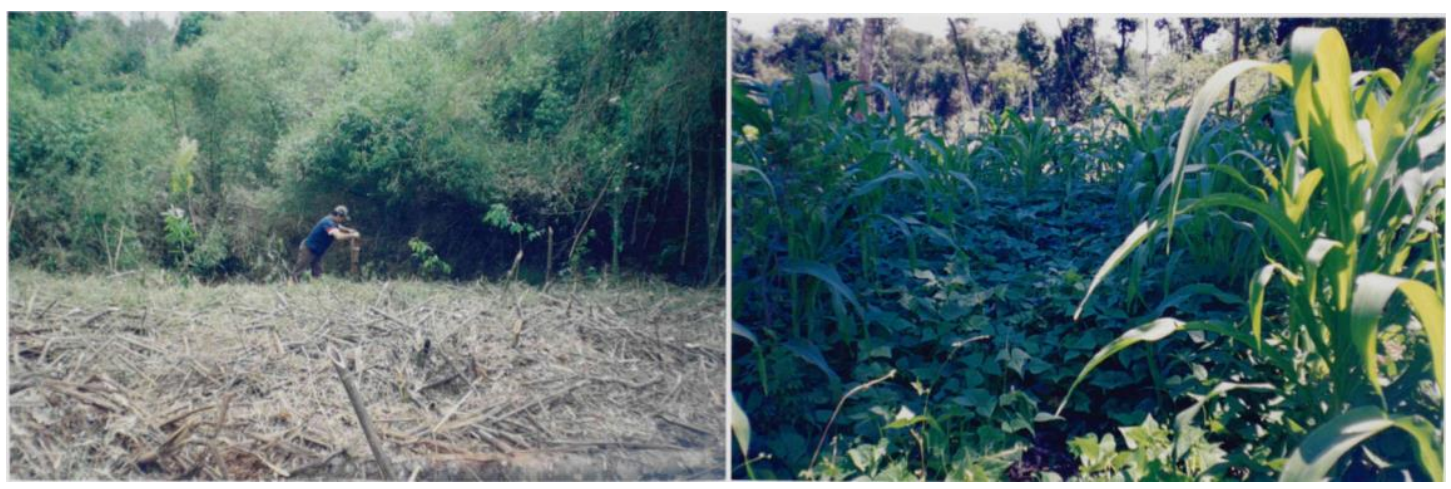

Fonte - Acervo de Elisângela Mocellin (2005).

Ademais, com a incerteza dos recursos e a necessidade do sustento da família, muitos agricultores aderiram à produção convencional. Dessa forma, no ano de 2010, daquelas famílias que aderiram à produção orgânica na comunidade dos Orgânicos, somente oito ainda desenvolviam esse sistema produtivo (BOZA et al., 2011).

Durante o trabalho de campo, pudemos notar, na fala dos entrevistados, que a falta de incentivos e apoio foi algo que desestimulou os agricultores: "faltou técnico, acompanhamento" (Entrevistado 3, 2018).

Outro entrevistado, assentado na comunidade dos Orgânicos, também relata as principais dificuldades enfrentadas que fizeram com que os agricultores fossem desestimulados quanto à produção agroecológica.

Depois que veio pros lotes, a dificuldade foi que o povo, nós, eu não conto, eu também não tinha condições [...] de plantar. Essa que foi a dificuldade nossa, nós não tinha... peguemos as terras inçadas, não tem como você bater, e era um colonião véio tampado... tudo no braço. [...] muito serviço, como é que vai limpar uma área de cinco alqueire? (Entrevistado 4, 2019).

O entrevistado se refere à dificuldade de trabalhar na área sem os equipamentos adequados para preparar a terra para o plantio. $O$ trabalho manual era insuficiente para viabilizar o controle das plantas na área da produção, considerando as práticas de manejo adotadas.

Outro crucial aspecto limitador para o avanço da Agroecologia, mencionado por Marcelites (2018, p. 105), foi a exígua atenção dispensada à estruturação dos circuitos de comercialização agroecológicos. Para o autor,

a falta de um mercado consumidor formado na região sem dúvida que impôs barreiras à produção orgânica, somada às dificuldades de acesso a financiamento tendo em vista que é requisito essencial acompanhamento técnico permanente na elaboração e execução de projetos voltados ao desenvolvimento da atividade, embora que nos primeiros anos houvesse assistência técnica, mas que depois por falta de recursos financeiros o Incra não disponibilizou mais esse serviço aos assentados.

A questão à qual o autor faz referência também se encontra na fala do Entrevistado 3 (2019) ao comentar a situação atual da produção agroecológica: "digo, vocês querem só saber a taxa que eu tenho que pagar por ano? 300, 400 conto que é a taxa da certificação, vocês não dá uma opção de venda, não corre atrás". O assentado faz menção à falta de canais de comercialização no município para a produção e manifesta descontentamento com o serviço dos técnicos da empresa contratada para a certificação que, segundo ele, não garantem a comercialização dos produtos. Rodrigues (2018, p. 51) relata que "no conjunto dos fatores limitantes ao processo produtivo das UPCs [Unidades de Produção Camponesas] em transição agroecológica, os principais envolveram questões que estão para além das porteiras das UPCs", ressaltando, sobretudo a exiguidade de políticas públicas.

Nesses termos, as muitas expectativas não alcançadas e a demora no acesso aos recursos foram as causas que mais desestimularam os agricultores, a ponto de inviabilizarem a produção. E, por fim, outro agricultor da comunidade dos Orgânicos reitera as dificuldades e fragilidades na esfera da comercialização como um ponto chave para o insucesso do projeto de produção agroecológico no assentamento: 
[...] o que deu mais errado pra nós aqui foi a decepção grande, foi a comercialização, porque é aquilo que a gente falou lá atrás na entrevista: você produz e na hora de vender não tem selo, não tem ninguém que absorva essa produção. Então antes de se pensar, a mensagem que eu deixo é o seguinte: é... primeiro você vê a comercialização. Primeiro porque pra dar condição pra quem tá trabalhando o resultado imediato do seu trabalho. (Entrevistado 2, 2019).

Essa situação fez com que os assentados da comunidade dos Orgânicos, já na primeira safra, se desmotivassem a trabalhar com a produção agroecológica e, aos poucos, passassem a usar agrotóxicos e outros produtos característicos da produção convencional. Não identificamos, durante o trabalho de campo, produção orgânica ou agroecológica nessa comunidade.

O quadro a seguir apresenta uma síntese dos motivos que contribuíram diretamente para desterritorialização da Agroecologia no assentamento.

Quadro 01 - Motivos para a desterritorialização da Agroecologia no assentamento Celso Futado - Comunidade dos Orgânicos e Palmital.

\begin{tabular}{|c|c|}
\hline $\begin{array}{l}\text { Aspecto } \\
\text { produtivo }\end{array}$ & $\begin{array}{l}\text { - Falta de planejamento na produção a fim de atender às necessidades de } \\
\text { autoconsumo e ao mercado; } \\
\text { - Baixa disponibilidade de maquinário adequado para diminuir a penosidade do } \\
\text { trabalho. }\end{array}$ \\
\hline $\begin{array}{c}\text { Aspecto } \\
\text { organizacional }\end{array}$ & $\begin{array}{l}\text { - } \begin{array}{l}\text { Processo formativo frágil sobre a importância e princípios da Agroecologia } \\
\text { durante a fase de acampamento; } \\
\text { - } \\
\text { Idealização da produção agroecológica (no período do acampamento), } \\
\text { desconsiderando as dificuldades para a sua viabilização no posterior } \\
\text { assentamento; } \\
\text { Falta de cumprimento dos prazos estipulados no período do acampamento } \\
\text { para a certificação, aquisição de maquinário e constituição de mercado no } \\
\text { assentamento; } \\
\text { Insuficiente atenção dada à estruturação dos circuitos de } \\
\text { comercialização; } \\
\text { Acompanhamento técnico insuficiente para o número de agricultores e tipo } \\
\text { de produção. }\end{array} \\
\end{array}$ \\
\hline $\begin{array}{l}\text { Políticas } \\
\text { públicas }\end{array}$ & $\begin{array}{l}\text { - Morosidade na liberação de recursos para a constituição da infraestrutura do } \\
\text { - } \quad \text { Aussentamento (estradas, casas, galpões etc.); } \\
\text { (financiamento da produção, assessoria técnica, riscos no processo de } \\
\text { transição e abertura de canais de comercialização). }\end{array}$ \\
\hline $\begin{array}{l}\text { Elementos } \\
\text { simbólicos/ } \\
\text { imateriais }\end{array}$ & $\begin{array}{l}\text { - Descompasso entre os conhecimentos agroecológicos dos assentados, os } \\
\text { - } \quad \text { Decursos territoriais da área e o "projeto agroecológico" do assentamento; } \\
\text { assentamento, que exigiram um trabalho específico para a manutenção das } \\
\text { práticas agroecológicas; } \\
\text { - Concepção de Agroecologia muito estreita quando consideradas as } \\
\text { características territoriais do assentamento; } \\
\text { - Forte presença do sistema de agricultura convencional no imaginário coletivo } \\
\text { dos assentados. }\end{array}$ \\
\hline
\end{tabular}

Fonte - Organizado pelos autores com base em Boza et al. (2011), Silva et al. (2018), Silva (2018) e pesquisa de campo realizada em 2019.

Cabe apontar também que, além dos problemas identificados no quadro, a existência de políticas públicas consolidadas para o modelo produtivo do agronegócio, assim como a rede de instituições de assessoria alinhadas ao sistema convencional de produção agropecuária, foram fundamentais para a desterritorialização da Agroecologia. Nesse sentido, os agricultores encontraram maiores possibilidades de implementar suas dinâmicas produtivas, considerando-se a premência pela geração de renda, ao aderirem à produção convencional.

Nas unidades estudadas observamos, ainda, nas falas dos entrevistados, que a falta de mão de obra, a insuficiência de conhecimentos específicos sobre o manejo orgânico e a elevada demanda de trabalho 
que o sistema de produção agroecológico exige foram fatores limitantes para o retrocesso da produção na transição acampamento-assentamento. Um dos entrevistados, ao ser questionado sobre os fatores limitantes, afirma que:

É... na verdade, o principal limitante, assim, hoje, ele é a mão de obra. Tudo, como em uma propriedade agroecológica, tudo "invulta" em mão de obra e manejo, né? E como o manejo ele é meio braçal, pra se iniciar é bem complicado, né? É o maior, um dos maior limitante pras pessoas, né?, quando você já tem um sistema praticamente implantado e você adota os manejos adequados é... mão de obra se reduz e muito, mas pra se implantar o principal limitante é a mão de obra e o conhecimento, né? (Entrevistado 3, 2019).

Essa questão é destacada por Silva et al. (2018, p. 46) quando afirmam que "as dificuldades de manejo também se constituíram como um fato complicador para a produção orgânica na comunidade Palmital". Rodrigues (2018, p. 39), na sua pesquisa sobre a comunidade Palmital, destaca que,

se por vezes os camponeses em transição agroecológica se submetem a trabalhos mais penosos, neste estudo se percebeu que isto não está relacionado a algum princípio ou característica da produção agroecológica. Tal fato está geralmente arrolada a fatores como a falta de recursos financeiros [...].

Após a formação do Assentamento, muitos agricultores das áreas destinadas ao desenvolvimento da Agroecologia não deram continuidade às práticas agroecológicas. Ocorreu, portanto, uma desterritorialização da Agroecologia.

A desterritorialização da Agroecologia no assentamento também é comprovada pelo trabalho de Rodrigues (2018). Em 2015, dados gerados pelo Centro de Desenvolvimento Sustentável e Capacitação em Agroecologia (CEAGRO) - instituição responsável pela assessoria técnica nas áreas de reforma agrária na região - apontaram à existência de vinte famílias em processo de transição agroecológica e de dez famílias produzindo agroecologicamente. Entretanto, das vinte famílias identificadas em 2015, apenas seis ainda se encontravam nesse processo no ano de $2018^{4}$.

\section{OS TERRITÓRIOS DA AGROECOLOGIA NO ASSENTAMENTO CELSO FURTADO}

Silva (2018), ao analisar as visões de mundo dos agricultores agroecológicos do assentamento Celso Furtado, identificou que esses sujeitos valorizam muito a questão ambiental, adotam o respeito à natureza como condição para o desenvolvimento de suas atividades, demostram preocupação com a saúde que os alimentos sem agrotóxicos proporcionam e consideram a terra como como um local de reprodução social, não como simples mercadoria. Além disso, alguns deles tiveram um contato precoce com o MST, fato que certamente contribuiu para que muitas ideias do movimento fossem incorporadas a sua visão social de mundo.

Apesar da desterritorialização da Agroecologia no assentamento, enquanto processo mais amplo empreendido pelas famílias assentadas, ainda há elementos desse sistema de produção no local. Trataremos, em seguida, do caso de uma família que trabalha com a produção do café agroecológico (na Comunidade 10 de Maio) e de outra família que produz frutas e hortaliças (na Comunidade Palmital).

A produção do café orgânico é um exemplo da territorialização da Agroecologia no Assentamento Celso Furtado, mesmo considerando seus limites em termos de abrangência da área (0,24 hectares). Esse cultivo presenta características importantes para tratar da prática agroecológica em contexto de reforma agrária.

A família possui uma área total de 12 hectares de terra que, em sua maior parte, está destinada ao sistema convencional. Contudo, foi isolado determinado espaço para a produção de café e frutas orgânicas. A família está inserida no MST desde o ano de 1999, quando veio do Paraguai. O primeiro

\footnotetext{
${ }^{4}$ Ressaltamos que o conceito de transição agroecológica não é definido com precisão nos textos que tratam de assentamentos. Assim, em alguns casos, uma unidade de produção considerada em transição para um determinado autor, pode ser considerada como agroecológica para outro.

\begin{tabular}{|c|c|}
\hline Caminhos de Geografia & Uberlândia-MG \\
\hline
\end{tabular}
}


contato que o entrevistado teve com a Agroecologia foi com apenas onze anos de idade, por meio de sua mãe, a qual participava de cursos de Agroecologia no Movimento.

Entretanto, o interesse em trabalhar com a produção de café veio de seu pai, também assentado e morador do mesmo lote, que de uma forma ou de outra, desenvolvia a produção de café por onde se estabelecia, mesmo em regiões que não são propícias para o desenvolvimento da cultura. Esse é o caso da região onde mora e desenvolve a produção de café no sistema de sombreamento.

Atualmente, o entrevistado possui 30 anos de idade e mora no lote de seus pais com sua esposa e uma filha. Investiu na produção agroecológica do café também pela frustação que teve com a produção convencional de leite. Seu pai foi quem iniciou o cultivo de café, porém, por conta da idade avançada, o entrevistado assumiu a produção, desenvolvendo e aperfeiçoando o processo de manejo, a produção e a colheita do produto.

Mesmo sem a certificação, o café é o principal produto comercializado nessa unidade de produção camponesa. Ademais, a família ainda produz frutas, todas em sistema orgânico: goiaba, mamão, abacaxi, amora e maracujá. Mesmo com uma produção tardia, o maracujá teve grande retorno financeiro no primeiro ano de produção: "Eu comercializei aí em torno de uns 800 quilos desses 200 pés" (Entrevistado 5 , 2019). Ainda que a produção de maracujá, no primeiro ano de produção, tenha rendido à família resultados satisfatórios, no segundo ano os agricultores tiveram dificuldades no controle da lagarta, o que acabou tornando a produção apenas para o autoconsumo.

A família cultiva o café em sistema de sombreamento, dado que a região não é própria para o desenvolvimento da produção cafeeira em função da incidência regular de geadas. Mesmo trabalhando sem a certificação, o manejo da produção continua sendo realizado seguindo os princípios ecológicos, de acordo com procedimentos do período em que a produção era certificada.

$\mathrm{Na}$ unidade de produção é encontrado café em vários estágios de desenvolvimento, o que dificulta a produção e a colheita. Segundo o agricultor entrevistado: "você vai ver que nós temos café em vários estágios e isso não...não, não ocorre numa região cafeeira, né? [...] Então isso, isso dificulta a produção porque você tem que vir aqui depois e colher só os cafezinhos maduros." (Entrevistado 5, 2019). Essa situação demanda acompanhamento e maior constância de mão de obra para o manejo.

O agricultor também relata a importância do sombreamento considerando as características físicas da área, como o clima e o regime de chuvas. Apesar de conseguir contornar essas características, ele reconhece que elas não contribuem positivamente para a produção. $O$ entrevistado ainda garante que se as geadas não forem intensas, a colheita rende em torno de $800 \mathrm{~kg}$ de café.

A assessoria técnica da unidade de produção é feita pelo Instituto Paranaense de Assistência Técnica e Extensão Rural (EMATER/PR). Se detectado algum tipo de problema na produção, a família logo solicita auxílio à Emater que, uma vez por mês, atende às demandas da sua unidade. Vale destacar ainda o incentivo que a unidade recebeu do CEAGRO, a partir de 2005, o qual incentivou os agricultores a produzirem para comercialização (Figuras 7 e 8). A família, inicialmente, plantou 800 pés de café e, após, plantou cerca de 250 pés a mais em um outro espaço reservado para a produção agroecológica. 0 agricultor e sua família pensam em fazer mudas de novas variedades com as 1.800 sementes que recebeu do Instituto Agronômico do Paraná (IAPAR). Além disso, pretendem utilizar em torno de mil mudas e fazer uma plantação nova durante o inverno. Assim, os conhecimentos, tanto aquele aprendido com o seu pai como aquele das instituições de assessoria, são requisitos essenciais para o desenvolvimento e sucesso na produção. 
Figuras 7 e 8 - Áreas de produção do café agroecológico - Assentamento Celso Furtado, 2019.
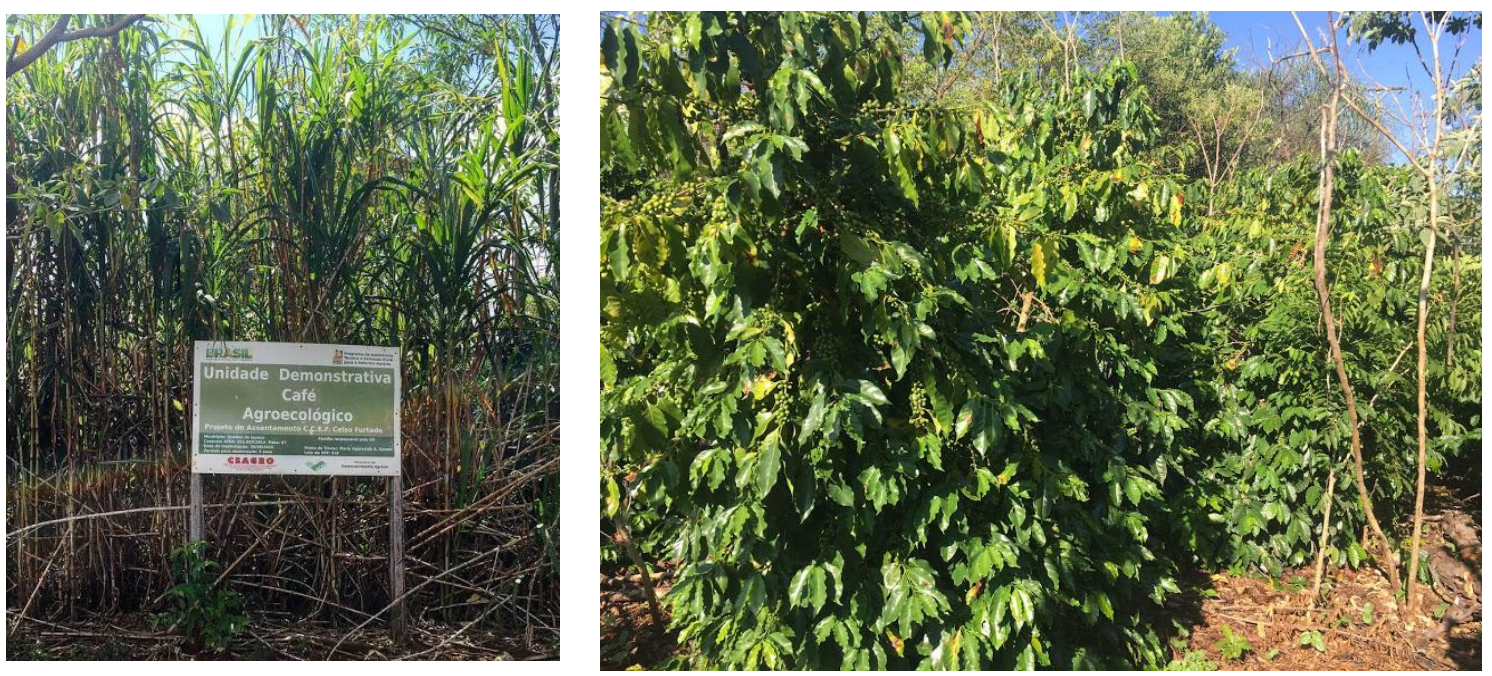

Fonte - Autores, 2019.

O assentado ressalta a importância do trabalho desenvolvido pelo CEAGRO em relação ao café:

Aí, depois que iniciou assistência técnica, mais precisamente do pessoal do CEAGRO, daí, né, que surgiu o incentivo de... do cultivo um pouco maior a nível mais de, pro excedente se comercializar. [...] Mas assim, com muita, com muito foco nisso, a gente achando que não, que não daria resultado e realmente o café, ele não, ele não dá resultado nenhum se não for nesse sistema, né? Se fosse no sistema convencional, não tinha um pé de café aqui pra comercializar (Entrevistado 5, 2019).

Ainda, destaca que, o retorno que tem, em uma média mensal, fica em torno de 450 a 500 reais: "se for fazer a soma mensal, é logico que a gente tem mês que a gente quase não vende, mas tem mês que você vende um volume bem maior, né? Quando a gente envia pra uma feira grande, mas gira em torno de um 450, 500 reais de café". (Entrevistado 5, 2019).

A venda da produção é feita utilizando-se diferentes canais de comercialização, mas as feiras, realizadas tanto pela EMATER/PR como pelo MST, constituem-se no principal local para o comércio. O café também é vendido em feiras na cidade de Quedas do Iguaçu e para consumidores individuais que procuram pelo produto na unidade de produção.

O processo de plantação, limpeza, colheita e torra, como já elencado anteriormente, é feito por toda a família. Quanto ao processo de empacotamento, é o agricultor entrevistado que o realiza, individualmente, uma vez que, segundo ele, "embalar, eu gosto eu mesmo de embalar ali, porque são detalhes que influencia na qualidade da aparência" (Entrevistado 5, 2019).

No processo de torra, o produtor utiliza de uma máquina denominada "torrador bolinha", a qual aprendeu a manusear com o grupo do IAPAR. O café, em seu estado pronto para ser torrado, é colocado dentro dessa máquina, que vai ao fogo e é girada manualmente de 14 a 22 minutos para torrar o café. O tempo no fogo vai determinar o sabor do produto.

Por fim, como podemos identificar na fala do entrevistado, o café é de suma importância para a família e contribui na geração de renda:

O café em si, ele é uma renda, considerando o tamanho de terra ele é uma renda muito boa, né? Porque ali a gente tem em torno de 2.300 metros quadrados que, esse ano, me proporcionou em torno de 10 mil reais de renda bruta, digamos assim, né? Daí tu tem que tirar se for colocar a mão de obra, o custo de embalagem, enfim, custo de produção, né? Mas uma renda bruta de em torno de 10 mil reais numa área de 2.300 metros quadrados. (Entrevistado 5, 2019).

A produção agroecológica do café demonstra a viabilidade produtiva e econômica da Agroecologia, ainda que a produção hegemônica seja em sistema convencional. Assim, é válido o esforço para que a produção convencional não seja o único sistema para a produção de alimentos. O café agroecológico, 
como apresentado, possibilitou à família autonomia para que pudesse escolher permanecer na unidade de produção, fazendo do café uma fonte de renda que atenda às suas necessidades.

Outra situação relacionada com a produção agroecológica foi encontrada na comunidade Palmital. O Entrevistado 3, e sua esposa também desenvolvem a produção com base nos princípios da Agroecologia. Natural de Cruzeiro do Iguaçu (PR), o agricultor iniciou a sua participação na luta pela terra no ano de 2000, com sua esposa e os três filhos. A família optou pelo grupo com produção orgânica, quando foram para o acampamento 10 de Maio, por conta da experiência de trabalho na agricultura, bem como pelo interesse em não utilizar agrotóxicos.

A família possui uma área total de 16 hectares, na qual faz plantação de diferentes produtos. Segundo o agricultor: "aqui o pontapé inicial, aqui, feijão, arroz, o básico; ali, né, mandioca, o milho produziu bastante também" (Entrevistado 3, 2019). Vale ressaltar que a produção, inicialmente, ocorreu em sistema agroecológico, porém a comercialização dos produtos foi como produção convencional, uma vez que a unidade de produção não estava certificada.

Entretanto, o agricultor parou a produção de milho por conta da quantidade de macacos que estavam destruindo a plantação, continuando com a produção de arroz e feijão somente para o autoconsumo da família. A partir disso, a família iniciou a plantação de frutas, sobretudo banana, mamão e maracujá. As frutas são comercializadas nas feiras do município de Quedas do Iguaçu.

A família também comercializa o leite, a sua principal fonte de renda. No entanto, segundo o agricultor, o leite não é produzido em sistema orgânico, mesmo possuindo em sua unidade toda a infraestrutura para manejo dos animais leiteiros nesse sistema de produção.

O agricultor destaca os problemas com a certificação e ressalta que isso, por si só, não garante a comercialização. Atualmente, ele conta com a certificação por auditoria, mas revela o seu descontentamento com o modelo:

\begin{abstract}
e então, essa nossa certificadora aqui não aceitava muitos produtos e, daí, não dava opção pra nós ir buscar ou trazer pra nós, então, daí, fiquemos de mãos amarradas. Eu peguei, até eu tô certificado, meu nome tá lá, mas não quero nem saber, não vou mais atrás, até esses dias eu falei pro homem [técnico responsável pela vistoria da certificadora], o homem nem adeus disse pra mim. Digo: vocês querem só saber a taxa que eu tenho que paga por ano? 300, 400 contos, que é a taxa da certificação; vocês não dá uma opção pra gente, cara, de venda, não corre atrás (Entrevistado 3, 2019).
\end{abstract}

O entrevistado ainda ressalta que não recebe nenhum tipo de assessoria técnica em sua unidade de produção camponesa atualmente. Declara que seu ponto de fragilidade na unidade se dá pela falta de mão de obra, considerando que somente ele e a sua esposa estão trabalhando. A falta de mão de obra, antes de representar a necessidade do uso intensivo do trabalho manual para a produção, revela a baixa disponibilidade de máquinas e o nível incipiente de tecnologias apropriadas para a produção agroecológicas disponível ao casal.

Os agricultores comercializam suas frutas em feiras de praças públicas, mais um fator que demonstra que a certificação não contribui para inserção no mercado sem que haja uma política pública específica para os agricultores agroecológicos. Esse fator é ponto de questionamento de muitos agricultores que trabalham com a mesma perspectiva.

Além dos dois casos citados, outros agricultores desenvolvem algum tipo de produção agroecológica em suas unidades, sobretudo para autoconsumo, mas não há produção com regularidade e em volume significativo para comercialização. Isso demonstra que a desterritorialização é relativa, já que há práticas em curso, assim como o potencial para a produção agroecológica, que pode vir a ser ativado em momentos e condições oportunas.

\title{
CONSIDERAÇÕES FINAIS
}

Nesta pesquisa abordamos, principalmente, o processo de desterritorialização da Agroecologia no Assentamento Celso Furtado. Retratamos o desenvolvimento da produção agroecológica nas áreas de acampamento, bem como o interesse dos sujeitos envolvidos nos grupos de produção, com o objetivo de desempenhar a produção no futuro assentamento.

A partir do momento em que os agricultores foram para os lotes, enfrentaram muitas dificuldades para desenvolver e manter a produção agroecológica. Inicialmente, da forma como relataram, receberam assessoria para iniciar no processo de transição e realizar o manejo considerando os princípios da

$\begin{array}{lllll}\text { Caminhos de Geografia } & \text { Uberlândia-MG } & \text { v. 21, n. } 77 & \text { Out/2020 } & \text { p. 111-132 Página } 128\end{array}$ 
Agroecologia. No entanto, com a demora na liberação dos recursos, a necessidade de produzir para atender à demanda familiar e às dificuldades do mercado, muitos agricultores desistiram da proposta agroecológica e partiram para a produção convencional.

Assim, coadunamos com Silva (2018, p. 102) quando afirma que na área estudada "a agroecologia chegou mais como um discurso político do que como um projeto viável para que os camponeses desenvolvessem autonomia." A orientação para o trabalho com base na Agroecologia proposta pelo MST encontra dificuldades de ser operacionalizada no cotidiano dos assentamentos. Isso resulta, em parte, dos próprios limites que o Movimento possui, como falta de recursos para viabilizar a produção e a assessoria técnica. Ao mudar a condição espacial dos sujeitos - do acampamento para o assentamento também foram alteradas as dinâmicas territoriais. É provável que desconsiderar ou não conseguir atender às expectativas produtivas e econômicas das famílias, por parte dos dirigentes e instituições de assessoria, após anos de acampamento, tenha sido o fator crucial para a situação relatada.

Cabe mencionar a concepção de Agroecologia para os assentados. Algumas ações e práticas identificadas durante a pesquisa - como a queimada para preparação da área para o plantio; a ideia de "limpar o mato" em vez de trabalhar o manejo das diferentes espécies; a desconsideração das potencialidades, enquanto recurso territorial, da vegetação de mata atlântica do assentamento denotam que muitos princípios da Agroecologia não foram considerados, tanto na divisão da área como nas práticas agrícolas adotadas. Nesse sentido, o projeto agroecológico para as comunidades, em termos de concepção e de execução, apresentou limites também do ponto de vista imaterial.

Outro complicador foi o que podemos definir como uma certa padronização do processo de transição agroecológica. As experiências particulares, que poderiam potencializar a produção agroecológica, foram sucumbidas diante da falta de um projeto mais consistente de transição para as famílias. Sem esse suporte, tanto do MST quanto das políticas públicas, a produção convencional apresentou-se mais segura para a geração de renda e reprodução da condição camponesa.

Ainda assim, alguns assentados não excluíram a produção agroecológica de suas unidades de produção camponesas, cultivando diferentes produtos nesse sistema de produção. Mesmo sem a certificação dos produtos ou um mercado consolidado que viabilize a comercialização da produção, os agricultores, como no caso do café e das frutas, praticam a Agroecologia. Em alguns casos, embora alguns produtores tivessem certificação orgânica da produção, nos primeiros anos de produção, isso não lhes garantiu mercado para os produtos. Percebe-se, portanto, a necessidade de uma política específica aos produtores agroecológicos, que possa potencializar o reconhecimento que o selo orgânico oferece.

Por fim, embora existam pessoas interessadas em trabalhar com a Agroecologia, é necessário que as políticas públicas contribuam para essa atividade. Considerando as particularidades que a luta pela terra engendra, relegar exclusivamente aos agricultores, acampados e assentados, a tarefa de desenvolver a Agroecologia é limitar o potencial transformador que ela apresenta.

\section{AGRADECIMENTOS}

Agradecemos ao Conselho Nacional de Desenvolvimento Científico e Tecnológico - CNPq pelo financiamento do projeto "Prática agroecológica e desenvolvimento territorial em áreas de agricultura camponesa no Sul do Brasil: potencialidades, conflitualidades e conquistas" (Chamada Universal $\mathrm{MCTI} / \mathrm{CNPq}$ № 01/2016) que possibilitou desenvolver a pesquisa aqui apresentada; à Universidade Federal da Fronteira Sul - Campus Laranjeiras do Sul, pelo auxílio no trabalho de campo; e aos camponeses por compartilharem seu tempo e informações sobre a Agroecologia.

\section{REFERÊNCIAS}

ABA - ASSOCIAÇÃO BRASILEIRA DE AGROECOLOGIA. Carta Sergipana do XI Congresso Brasileiro de Agroecologia (XI CBA). 2019. Disponível em: https://aba-agroecologia.org.br/wpcontent/uploads/2019/11/XI-CBA-Agroecologia Carta-Sergipana.pdf. Acesso em: 21 de agosto de 2020.

ALTIERI, M. A. Agroecologia, agricultura camponesa e soberania alimentar. Revista NERA, ano 13, n. 16, p. 22-32, 2010.

ANTUNES, R. Adeus ao trabalho? Ensaio sobre as metamorfoses e a Centralidade do Mundo do Trabalho. São Paulo: Cortez; Editora da UNICAMP, 2003. 9. ed.

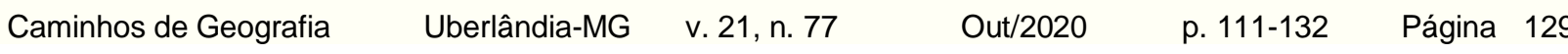


BALSAN, R. Impactos decorrentes da modernização da agricultura brasileira. Campo-território: revista de geografia agrária, v. 1, p. 123-151, 2006.

BORSATTO, R. S.; CARMO, M. S. A Construção do Discurso Agroecológico no Movimento dos Trabalhadores Rurais Sem-Terra (MST). RESR, v. 51, p. 645-660, 2013. https://doi.org/10.1590/S010320032013000400002

BOZA, C; PEREIRA, M. F. C. S; XAVIER, L. P. A formação, a evolução e o fim da Brigada Orgânica do Assentamento Celso Furtado, PR. Cadernos de Agroecologia (Resumos do VII Congresso Brasileiro de Agroecologia), Fortaleza/CE, v. 6, p. 01-04, 2011.

BRASIL. Lei n. 10.831, de 23 de dezembro de 2003. Dispõe sobre a agricultura orgânica e dá outras providências. Brasília, DF: Presidência da República, 2003. Disponível em: http://www.planalto.gov.br/ccivil 03/leis/2003/110.831.htm. Acesso em: 17 de agosto de 2020.

CAPORAL, F. R. Agroecologia: uma nova ciência para apoiar a transição a agriculturas mais sustentáveis. In: FALEIRO, F. G.; FARIAS NETO, A. L. de. (Org.). Savanas: desafios e estratégias para o equilíbrio entre sociedade, agronegócio e recursos naturais. Brasília: Embrapa Cerrados, p. 895-929, 2008.

CAVALCANTE, M.; FERNANDES, B. M. Territorialização do agronegócio e concentração fundiária. Revista NERA, ano 11, n. 13, p. 16-25, 2008.

DATALUTA. Banco de Dados da Luta pela Terra. Relatório Brasil 2017. Disponível em: http://www2.fct.unesp.br/nera/relatoriosbr.php. Acesso em: 09 de novembro de 2019.

DELGADO, G. C. Questão agrária no Brasil, 1950-2003. In: JACCOUD, L. Questão social e políticas sociais no Brasil contemporâneo. Brasília: IPEA, p. 51-90, 2005.

EDUARDO, M. F. Território, trabalho e poder: por uma geografia relacional. CAMPO - TERRITÓRIO: REVISTA DE GEOGRAFIA AGRÁRIA, v. 1, p. 173-195, 2006.

FABRINI, J. E.; ROOS, D. Conflitos territoriais entre o campesinato e o agronegócio latifundiário. São Paulo: Outras Expressões, 2014.

FACCO, V. A. B. Alternativas aos impérios agroalimentares a partir do campesinato agroecológico: as experiências do acampamento agroflorestal José Lutzenberger (MST-Antonina/PR). Revista NERA, ano 18, n. 29, p. 70-100, 2015.

FERNANDES, B. M. Questão Agrária: conflitualidade e desenvolvimento territorial. In: BUAINAIN, A. M. et al. (Org.). Luta pela Terra, Reforma Agrária e Gestão de Conflitos no Brasil. Campinas: Editora da Unicamp, p. 173-224, 2008.

Construindo um estilo de pensamento na questão agrária: 0 debate paradigmático e 0 conhecimento geográfico. Tese (Livre Docência em Geografia) - Presidente Prudente: UNESP, 2013.

FERNANDES, G. M.; FACCO, V. A. B. Agroecologia e MST no leste paranaense: as experiências do assentamento Contestado (Lapa/PR) e do acampamento José Lutzenberger (Antonina/PR). Revista Pegada - MUNDO DO TRABALHO (número especial da XV Jornada do Trabalho), vol. 16, n. especial, p. 89-101, 2015. https://doi.org/10.33026/peg.v16i0.3524

FINATTO, R. A. Redes de agroecologia e produção orgânica na região Sul do Brasil. RA'EGA - O

Espaço Geográfico em Análise, v. 38, p. 107-145, dez. 2016. https://doi.org/10.5380/raega.v38i0.42242

FINATTO, R. A.; RIBAS, K. C. S. Desenvolvimento Territorial e Agroecologia: considerações sobre o acampamento Herdeiros da Terra de $1^{\circ}$ de Maio. In: VIII SIMPÓSIO INTERNACIONAL DE GEOGRAFIA AGRÁRIA E IX SIMPÓSIO NACIONAL DE GEOGRAFIA AGRÁRIA, 2017, Curitiba. Anais [...] Curitiba/Paraná, p. 1-12, 2017.

FONSECA, M. A. S. Questão agrária e produção de alimentos orgânicos no Distrito Federal - o caso do acampamento Chapadinha. Trabalho de Conclusão de Curso (Graduação em Agronomia) Brasília: UnB. 2017. 
INCRA - INSTITUTO NACIONAL DE COLONIZAÇÃO E REFORMA AGRÁRIA. Incra nos Estados Informações gerais sobre os assentamentos da Reforma Agrária. Disponível em: http://painel.incra.gov.br/sistemas/index.php. Acesso em: 12 jan. 2020.

LEFF, H. Agroecologia e saber ambiental. Agroecologia e Desenvolvimento Rural Sustentável, v. 3, p. 36-51, 2002.

MARCELITES, E. J. As relações contraditórias de produção no assentamento Celso Furtado no município de Quedas do Iguaçu, PR: subordinação e resistência. Dissertação (Mestrado em Agroecologia e Desenvolvimento Rural Sustentável) - Laranjeiras do Sul: UFFS. 2018.

Agroecologia e processos pedagógicos no Colégio Estadual do Campo Chico Mendes, Assentamento Celso Furtado, Quedas do Iguaçu - PR. Monografia (Especialização em Educação do Campo) - Laranjeiras do Sul: UFFS. 2017.

MARTIM, N. A agroecologia e a conquista do território: o caso do acampamento Dom Tomás Balduíno, Quedas do Iguaçu (PR). In: VIII SIMPÓSIO INTERNACIONAL DE GEOGRAFIA AGRÁRIA E IX SIMPÓSIO NACIONAL DE GEOGRAFIA AGRÁRIA, 2017, Curitiba. Anais [...] Curitiba/Paraná, p. 1-14, 2017.

MARTINS, J. de S. $O$ cativeiro da terra. São Paulo: Editora Contexto, 2010.

MST - MOVIMENTO DOS TRABALHADORES RURAIS SEM TERRA. Programa Agrário do MST VI Congresso Nacional do MST - Fevereiro de 2014. In: CALDART, R. S.; ALENTEJANO, P. (Org.). MST, Universidade e Pesquisa. São Paulo: Editora Expressão Popular, p. 173-225, 2014.

OLIVEIRA, A. U. A agricultura camponesa no Brasil. São Paulo: Contexto, 2001a.

A longa marcha do campesinato brasileiro: movimentos sociais, conflitos e Reforma Agrária. Estudos Avançados, v. 15, p. 185-206, 2001b. https://doi.org/10.1590/S0103-40142001000300015

PAULINO, E. T.; FABRINI, J. E. (Org.). Campesinato e territórios em disputa. São Paulo: Expressão Popular, 2008.

PICCIN, M. B. Acampamento, Agroecologia e Assentamento Rural. (Resumos do VI CBA e II CLAA). Rev. Bras. de Agroecologia, v. 4, p. 517-521, 2009.

PICOLOTTO, E. L. e PICCIN, M. B. Movimentos camponeses e questões ambientais: positivação da agricultura camponesa? Revista Extensão Rural, ano XV, n. 16, p. 05-36, 2008.

RAFFESTIN, C. O que é o território? In: Por uma geografia do poder. São Paulo: Editora Ática S. A., p. 143-163, 1993.

RODRIGUES, B. S. Transição agroecológica e as necessidades dos camponeses: o caso do assentamento Celso Furtado no município de Quedas do Iguaçu-PR. Trabalho de Conclusão de Curso (Graduação em Agronomia) - Erechim e Pontão: UFFS. 2018.

ROOS, D. A luta pela terra em Quedas do Iguaçu e a conquista camponesa dos assentamentos Celso Furtado e Rio Perdido. Revista Eletrônica da Associação dos Geógrafos Brasileiros - Seção Três Lagoas/MS, n. 13, p. 53-86, 2011.

GUZMÁN, E. S. De la sociología rural a la agroecologia. Barcelona: Icaria. 2006.

Uma estratégia de sustentabilidade a partir da Agroecologia. Agroecologia e Desenvolvimento Rural Sustentável, n.1, p. 35-45, 2001.

SILVA, P. G. A incorporação da Agroecologia pelo MST: reflexões sobre o novo discurso e experiência prática. Dissertação (Mestrado em História) - Niterói: UFF. 2011.

SILVA, E. F. Entre ideologias e utopias: visões de mundo dos agricultores agroecológicos do assentamento Celso Furtado em Quedas do Iguaçu-PR. Dissertação (Mestrado em Desenvolvimento Rural Sustentável) - Marechal Cândido Rondon: UNIOESTE. 2018. 
SILVA, E. F.; PAVINATO, J. M. S.; AHLERT, A. Desafios da produção agroecológica no assentamento Celso Furtado em Quedas do Iguaçu-PR. Revista GeoPantanal, n. 24, p. 35-51, 2018.

SOUZA, M. J. L. O território: sobre espaço e poder, autonomia e desenvolvimento. In: CASTRO, I. E.; GOMES, P. C. C.; CORREAA, R. L. (Org.). Geografia: Conceitos e Temas. Rio de Janeiro: Bertrand Brasil, p. 77-116, 2000.

ZENERATTI, F. L. Propriedade e latifúndio: introdução ao debate sobre sua origem e perpetuação no Brasil. Caderno de Geografia, v. 27, p. 441-454, 2017. https://doi.org/10.5752/p.23182962.2017v27n50p441

WEZEL, A.; BELLON, S.; DORÉ, T.; FRANCIS, C.; VALLOD, D.; DAVID, C. Agroecology as a science, a movement and a practice. A review. Agronomy for Sustainable Development, v. 29, p. 503-515, 2009. https://doi.org/10.1051/agro/2009004

Recebido em: 20/12/2019

Aceito para publicação em: 26/08/2020 